\title{
ADSORPSI ASETON PADA ARANG AKTIF BIJI ASAM JAWA
}

\author{
Audy D. Wuntu ${ }^{1)}$ dan Vanda S. Kamu ${ }^{1)}$ \\ e-mail: untudenny@yahoo.com \\ ${ }^{1)}$ Program Studi Kimia FMIPA Universitas Sam Ratulangi Manado, 95115
}

\begin{abstract}
ABSTRAK
Telah diteliti adsorpsi aseton pada arang aktif yang dibuat dari biji asam jawa (Tamarindus indica) yang diaktivasi dengan $\mathrm{NaCl}$. Penelitian ini bertujuan untuk menentukan parameter adsorpsi, yaitu kapasitas dan energi adsorpsi. Parameter tersebut dihitung dari persamaan regresi linear yang diperoleh dari data adsorpsi aseton pada arang aktif dalam sistem tertutup yang dianalisis menggunakan model isotherm adsorpsi Dubinin-Raduskevich. Sebagai pembanding, prosedur yang sama diterapkan pada arang aktif komersil yang terbuat dari tempurung kelapa. Hasil yang diperoleh menunjukkan bahwa kapasitas adsorpsi aseton pada arang aktif yang dibuat dari biji asam jawa $\left(6,85 \times 10^{-2} \mathrm{~cm}^{3} / \mathrm{g}\right)$ lebih rendah dari kapasitas adsorpsi aseton pada arang aktif komersil $\left(8,98 \times 10^{-2} \mathrm{~cm}^{-3} / \mathrm{g}\right)$. Kecenderungan yang sama teramati juga pada nil;ai energy adsorpsi, yaitu 7,69 $\mathrm{kJ} / \mathrm{mol}$ pada arang aktif biji asam jawa dan $8,08 \mathrm{~kJ} / \mathrm{mol}$ pada arang aktif komersil. Untuk meningkatkan kualitas arang aktif biji asam jawa, perlu dilakukan perbaikan dalam proses pembuatan arang aktif preparasi.
\end{abstract}

Kata kunci: adsorpsi, asam jawa, karbon aktif

\section{ACETONE ADSORPTION ON TAMARIND SEED ACTIVATED CARBON}

\begin{abstract}
The adsorption of acetone on activated carbon prepared from tamarind (Tamarindus indica) seed activated with $\mathrm{NaCl}$ was investigated. The investigation was aimed to calculate the adsorption parameters which were adsorption capacity and energy of acetone on the adsorbent. The parameters were calculated using linear regression equation derived from data of acetone adsorption on the activated carbon in a closed system which was analyzed using DubininRaduskevich adsorption isotherm model. As a comparison, the same procedure was performed on commercial coconut shell activated carbon. The results showed that the adsorption capacity of acetone on tamarind seed activated carbon $\left(6.85 \times 10^{-2} \mathrm{~cm}^{3} / \mathrm{g}\right)$ was lower than that on commercial one $\left(8.98 \times 10^{-2} \mathrm{~cm}^{3} / \mathrm{g}\right)$. The similar trend was observed in the adsorption energy values which were $7.69 \mathrm{~kJ} / \mathrm{mol}$ on tamarind seed activated carbon and $8.08 \mathrm{~kJ} / \mathrm{mol}$ on commercial activated carbon. It was suggested that the preparation of tamarind seed to produce activated carbon should be improved.
\end{abstract}

Keywords : adsorption, tamarind, activated carbon

\section{PENDAHULUAN}

Masyarakat perkotaan cenderung menggunakan pengatur udara (AC, Air Conditioner) sebagai pendingin ruangan tertutup. Pemakaian peralatan seperti ini menyebabkan laju pertukaran udara dalam ruangan dengan luar ruangan menjadi kecil sehingga terjadi penurunan kualitas udara dalam ruangan tertutup dengan adanya peningkatan konsentrasi partikulat, karbondioksida, karbon monoksida, bakteri dan senyawa organik yang mudah menguap
(VOC, volatile organic compounds). Samfield (1992) mengemukakan bahwa tidak kurang dari 220 jenis kontaminan organik volatil dapat ditemukan dalam lingkungan udara ruangan tertutup, diantaranya adalah aseton, benzena, asetaldehida, etilbenzena, metil etil keton, toluena, trikloroetana dan $p$ xilena.

Aseton pada suhu kamar adalah larutan jernih, tidak berwarna, bersifat volatil dengan bau aromatik menyerupai benzena dan mudah terbakar, sehingga aseton merupakan zat pembakar berbahaya yang 
signifikan pada suhu kamar. Aseton dalam ruangan dapat berasal dari cat, vernis dan pewangi ruangan. Aseton dapat mengiritasi kulit, mata, dan saluran pernafasan dan telah diketahui bahwa kontak dengan kontaminan organik dalam waktu yang lama dapat meningkatkan risiko gangguan kesehatan serius pada manusia akibat sifat karsinogenik dan mutageniknya.

Berbagai metode telah dikembangkan untuk meningkatkan kualitas udara dalam ruangan tertutup, diantaranya adalah filtrasi, pembentukan ion dan presipitasi elektrostatik. Meskipun metode filtrasi cukup efektif untuk menyingkirkan partikel tersuspensi tetapi metode ini tidak mampu menghilangkan senyawa organik volatil dari udara (Energy Services, 2006). Metode lain seperti pembentukan ion dan presipitasi elektrostatik memang mampu menghilangkan senyawa organik volatil tetapi kedua metode ini justru dapat menimbulkan masalah baru karena dapat menghasilkan gas ozon yang berbahaya bagi paru-paru (Wisconsin Division of Public Health, 2002). Metode lain yang dapat digabungkan dengan metode filtrasi adalah metode adsorpsi melalui penggunaan adsorben yang mampu mengadsorpsi senyawa organik volatil. Terdapat berbagai jenis adsorben yang telah lama dikenal, diantaranya yaitu zeolit dan arang aktif. Pemanfaatan zeolit sebagi pembersih udara telah dikemukakan oleh Massenbauer et al. (2007), tetapi zeolit dengan spesifikasi khusus untuk pemurnian udara bukanlah material yang mudah diperoleh. Material adsorben lain yang relatif lebih mudah diperoleh dan telah terbukti kemampuannya untuk adsorpsi VOC adalah arang aktif.

Arang aktif dapat dibuat dari berbagai bahan baku, diantaranya dari bijibijian tanaman tertentu seperti asam jawa (Tamarindus indica). Di banyak tempat, bagian tanaman asam jawa yang banyak dimanfaatkan adalah daging buahnya untuk dijadikan pelengkap bahan tambahan untuk pangan sedangkan bagian bijinya tidak dimanfaatkan dan dibuang sebagai limbah. Pemanfaatan biji asam jawa telah diteliti untuk digunakan sebagi koagulan dalam pengolahan limbah cair. Dalam makalah ini dikemukakan hasil penelitian pemanfaatan biji asam jawa sebagai arang aktif untuk adsorpsi aseton dalam ruang tertutup, khususnya menyangkut kapasitas dan energi adsorpsi aseton dengan pendekatan isoterm adsorpsi Dubinin-Raduskevich (DR).

\section{METODOLOGI PENELITIAN}

Penelitian ini dilaksanakan dalam dua tahap utama, (1) yaitu pembuatan arang aktif dari biji asam jawa dan (2) eksperimen adsorpsi aseton pada arang aktif biji asam jawa.

\section{Pembuatan Arang Aktif Biji Asam Jawa}

Mula-mula biji asam jawa kering dihaluskan hingga berbentuk butiran dan dipanaskan dalam tanur pada suhu $400{ }^{\circ} \mathrm{C}$ selama setengah jam. Arang yang dihasilkan selanjutnya diaktivasi melalui perendaman dalam $\mathrm{NaCl} 50 \%$ selama 24 jam diikuti pemanasan dalam tanur pada suhu $600{ }^{\circ} \mathrm{C}$ selama dua jam. Arang aktif yang dihasilkan selanjutnya dicuci dengan akuades dan dikeringkan dalam oven pada suhu $110{ }^{\circ} \mathrm{C}$. selama tiga jam.

\section{Eksperimen Adsorpsi Aseton}

Sebanyak 100 gram arang aktif tempurung kelapa ditempatkan dalam krus porselen dan dimasukkan dalam oven pada suhu $105{ }^{\circ} \mathrm{C}$ selama 3 jam. Kemudian didinginkan dalam desikator selama 30 menit. Arang aktif selanjutnya ditimbang sebanyak 10 gram dan dimasukkan dalam tabung kaca yang mempunyai dua ujung yang terbuka. Tabung tersebut kemudian dimasukkan dalam wadah plastik tertutup berukuran $5 \mathrm{~L}$.

Dalam wadah plastik tersebut diletakkan kipas angin kecil dengan posisi membelakangi tabung yang berisi arang aktif. Selanjutnya dimasukkan $0,2 \mathrm{~mL}$ aseton dalam wadah plastik tanpa menyentuh arang aktif dan sesegera mungkin wadah plastik ditutup serta kipas angin dihidupkan. Aseton menguap dalam wadah plastik tertutup dan uap aseton secara dinamis akan keluar masuk melewati arang aktif yang kemudian akan mengadsorpsi uap aseton hingga tercapai kesetimbangan. Tahap ini berlangsung selama 24 jam. Setelah 24 jam, arang aktif dikeluarkan dari wadah plastik tertutup dan ditimbang beratnya. Jumlah selisih berat arang aktif sebelum dan sesudah adsorpsi adalah berat aseton yang teradsorpsi pada 
arang aktif. Prosedur ini dikerjakan untuk volume aseton pada kisaran 0,2 hingga $1 \mathrm{~mL}$. Eksperimen adsorpsi juga dilakukan untuk adsorben arang aktif komersil yang diperoleh di pasaran sebagai pembanding.

\section{Analisis Data}

Data yang diperoleh selanjutnya dianalisis menurut model isoterm adsorpsi Dubinin-Raduskevich (DR) untuk menentukan kapasitas dan energi adsorpsi aseton pada arang aktif biji asam jawa dan arang aktif komersil:

$$
\begin{gathered}
\mathrm{W}=\mathrm{W}_{\mathrm{o}} \exp \left[-\left(\mathrm{A} /\left(\beta \mathrm{E}_{\mathrm{o}}\right)\right)^{2}\right] \\
\mathrm{A}=\mathrm{RT} \ln \left(\mathrm{P}_{\mathrm{o}} / \mathrm{P}\right)
\end{gathered}
$$

$\mathrm{W}=$ volume aseton teradsorpsi $\left(\mathrm{cm}^{3} / \mathrm{g}\right)$

$\mathrm{W}_{\mathrm{o}}=$ volume total pori mikro yang dapat diakses aseton $\left(\mathrm{cm}^{3} / \mathrm{g}\right)$

$\mathrm{P}=$ tekanan parsial aseton (atm)

$\mathrm{P}_{\mathrm{o}}=$ tekanan uap jenuh aseton (atm)

$\mathrm{E}_{\mathrm{o}}=$ energi adsorpsi $\left(\mathrm{kJ} \mathrm{mol}^{-1}\right)$ $\beta=$ rasio potensial adsorpsi adsorbat dan adsorbat standar (konvensi $\beta_{\text {aseton }}=1$ )

$\mathrm{R}=$ konstanta gas $\left(8,314 \mathrm{~J} \mathrm{~K}^{-1} \mathrm{~mol}^{-1}\right)$

$\mathrm{T}=$ suhu mutlak $(\mathrm{K})$

Bentuk persamaan linear model isoterm adsorpsi DR adalah:

$\ln \mathrm{W}=\ln \mathrm{W}_{\mathrm{o}}-\left[\left(1 /\left(\beta \mathrm{E}_{\mathrm{o}}\right)\right]^{2}\left[\mathrm{RT} \ln \left(\mathrm{P}_{\mathrm{o}} / \mathrm{P}\right)\right]^{2}\right.$ Kapasitas adsorpsi dihitung dari intercept dan energi adsorpsi dihitung nilai slope.

\section{HASIL DAN PEMBAHASAN}

Kapasitas adsorpsi adalah banyaknya volume dari total pori arang aktif yang dapat diakses oleh aseton. Kapasitas adsorpsi arang aktif biji asam jawa dan arang aktif komersil ditentukan dari persamaan linear lewat plot ln $\mathrm{W}$ vs. [RT $\left.\ln \left(\mathrm{P}_{\mathrm{o}} / \mathrm{P}\right)\right]^{2}$ menurut model isoterm adsorpsi Dubinin-Raduskevich (DR) (Gambar 1).

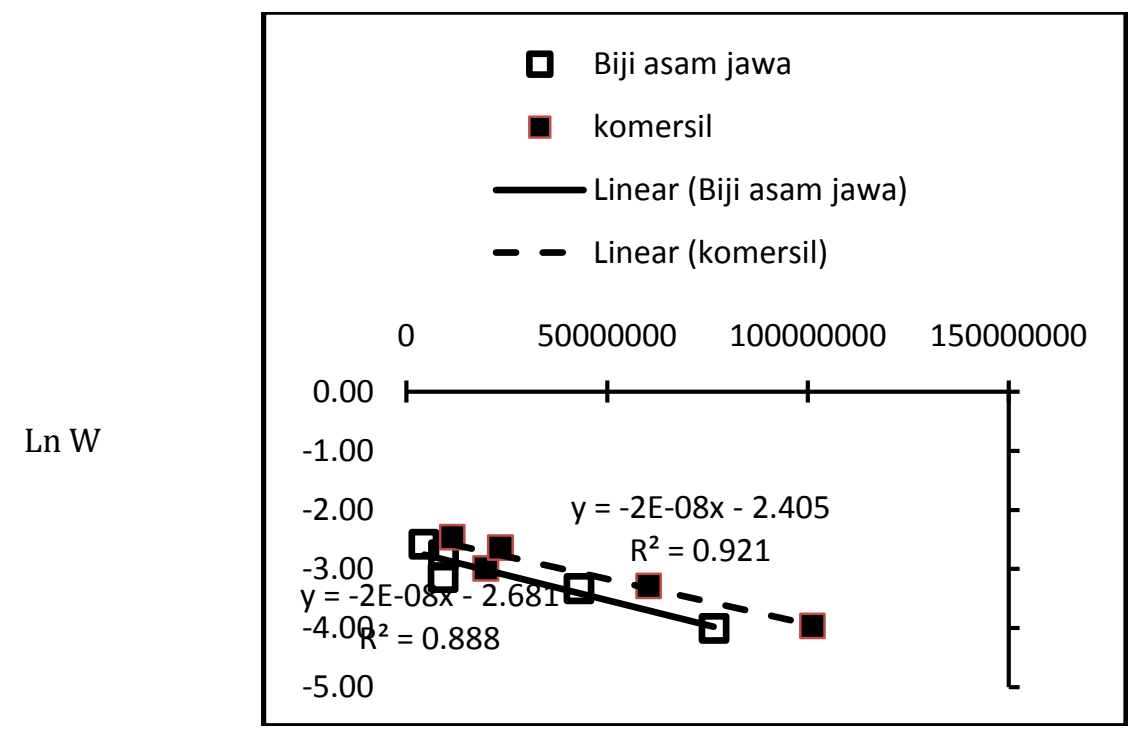

Gambar 1. Linearitas isoterm adsorpsi DR aseton pada arang aktif biji asam jawa ( $\boldsymbol{\square})$ dan arang aktif komersil

Dari nilai intercept persamaan regresi linear tersebut dapat ditentukan nilai kapasitas adsorpsi arang aktif biji asam jawa untuk aseton adalah $6,85 \times 10^{-2}$ $\mathrm{cm}^{3} / \mathrm{g}$. Nilai ini lebih rendah jika dibandingkan dengan kapasitas adsorpsi arang aktif komersial sebesar $8,98 \times 10^{-2}$ $\mathrm{cm}^{3} / \mathrm{g}$. Arang aktif komersil yang dipergunakan dalam penelitian ini adalah arang aktif tempurung kelapa yang diperoleh langsung dari perusahaan pembuat arang aktif tempurung kelapa. Proses aktivasi fisik pada suhu tinggi yang diterapkan pada arang tempurung kelapa sepertinya menghasilkan arang aktif dengan kualitas yang lebih baik dibandingkan arang aktif biji asam jawa yang diaktivasi secara kimia 
menggunakan $\mathrm{NaCl}$. Hal ini terlihat pada kadar abu arang aktif biji asam jawa yang mencapai 10,13\% dan kadar karbon terikat $79,91 \%$. Tingginya kadar abu dan rendahnya kadar karbon terikat merupakan masalah yang menyebabkan rendahnya kapasitas adsorpsi arang aktif biji asam jawa.

Parameter kedua yang dikaji dalam penelitian ini adalah energi adsorpsi. Energi adsorpsi merupakan energi yang dibutuhkan untuk memutuskan ikatan antara adsorben dan adsorbat. Dari persamaan regresi linear adsorpsi menurut model isoterm adsorpsi DR dapat dihitung nilai energi adsorpsi aseton pada arang aktif biji asam jawa sebesar 7,69 kJ/mol dan pada arang aktif komersil sebesar $8,08 \mathrm{~kJ} / \mathrm{mol}$. Nilai-nilai energi adsorpsi ini masih berada dalam kisaran energi adsorpsi fisik $(<62,76$ $\mathrm{kJ} / \mathrm{mol}$ ) (Bare and Somorjai, 1987). Adsorpsi fisik dapat disebabkan oleh gaya tarik-menarik yang melibatkan gaya-gaya van der Waals seperti interaksi dipol-dipol dan interaksi dipol terinduksi. Aseton adalah senyawa yang kurang polar sehingga dapat berinteraksi dengan arang aktif yang bersifat non polar melalui interaksi dipol terinduksi. Interaksi ini merupakan gaya van der Waals lemah sehingga hanya diperlukan sedikit energi untuk memutuskan ikatan antara arang aktif dengan adsorben. Hal ini dapat memberi keuntungan dalam kaitannya dengan penggunaan berulang adsorben. Pemutusan ikatan yang lemah ini dapat dilakukan hanya dengan sedikit pemanasan.

\section{KESIMPULAN}

Biji asam jawa dapat diolah menjadi arang aktif melalui proses karbonisasi dan aktivasi konvensional menggunakan $\mathrm{NaCl}$ meskipun cara ini menghasilkan arang aktif dengan mutu lebih rendah dari arang aktif tempurung kelapa komersil. Untuk mendapatkan arang aktif biji asam jawa berkualitas lebih baik perlu dikaji proses pembuatan yang lebih baik baik pada tahap karbonisasi maupun aktivasi.

\section{DAFTAR PUSTAKA}

Bare, S. R., G. A. Somorjai. 1987. Surface Chemistry Engineering, Encyclopedia of Physical Science and Technology Vol. 16. Academic Press, Inc.

Energy Services. 2006. Energy Efficiency and Indoor Air Quality. Energy Services, Western Area Power Administration. Lakewood, USA.

Massenbauer, I. A., B. M. C. Neirynck, J. R. G. Strafe. 2007. Method and Apparatus for Improving the Air Quality Within a Building or Enclosed Space. Patent No.20070039465. http://www.freshpatents.com.

Samfield, M. M. 1992. Indoor Air Quality Database for Organic Compounds. United States Environmental Protection Agency. EPA-600-R-92-025.

Wisconsin Division of Public Health. 2002. Home Air Cleaners. Wisconsin Division of Public Health Bureau of Environmental Health. Madison Wisconsin. Http://www.dhfs.state.wi.us/eh 